Web Jurnal:

http://ejournal.kemenperin.go.id/jli

\title{
Peningkatan daya buih susu skim sebagian rekombinasi dengan penggunaan penstabil
}

\section{Foamability improvement of recombined part-skim milk by addition of stabilizer}

\author{
Ahmad Johari*1, Sugiyono², dan Dede Robiatul Adawiyah ${ }^{2}$ \\ 1 Program Studi Magister Teknologi Pangan, Sekolah Pascasarjana, Institut Pertanian Bogor \\ Jl. Raya Dramaga, Bogor, Indonesia \\ 2 Departemen Ilmu dan Teknologi Pangan, Fakultas Teknologi Pertanian, Institut Pertanian Bogor \\ Jl. Raya Dramaga, Bogor, Indonesia \\ *e-mail: ahmadjohari2@gmail.com
}

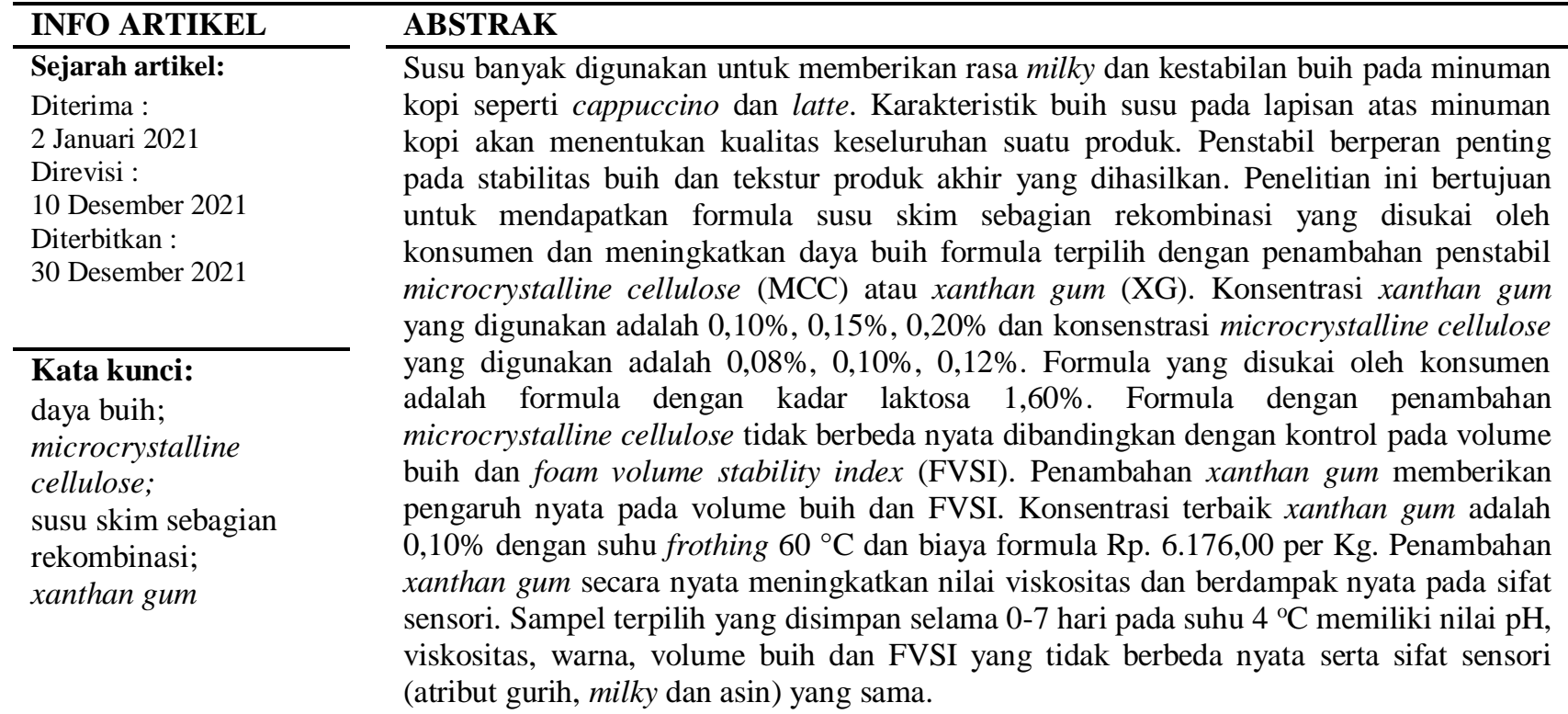

Keywords:
foamability;
microcrystalline
cellulose;
recombined part-skim
milk;
xanthan gum.

\begin{abstract}
Milk is widely used to give milky flavor and increase the stability of foam required for cappuccino and latte. The characteristic of the foam layer at coffee beverages determines the overall quality of the product. A stabilizer plays an important role in the foam stability and texture of the product. The aim of this study was to formulate recombined part-skim milk preferred by consumers and improve foamability by adding stabilizers, i.e. microcrystalline cellulose or xanthan gum. Xanthan gum added were 0,10\%, 0,15\%, $0,20 \%$ and microcrystalline cellulose added were 0,08\%, 0,10\%, 0,12\%. The formula with $1,60 \%$ lactose was preferred by consumers. The formulas with microcrystalline cellulose were not significantly different from control in terms of foam volume and foam volume stability index (FVSI). However, the formulas with xanthan gum were significantly different from the control. The best concentration of xanthan gum was $0,10 \%$, frothing temperature $60{ }^{\circ} \mathrm{C}$, and price of formula $\mathrm{Rp}$. 6.176,00 per Kg. The addition of xanthan gum significantly increased the viscosity and affected the sensory properties. The preferred formula which had been stored for $0-7$ days at $4{ }^{\circ} \mathrm{C}$ showed stable $\mathrm{pH}$, viscosity, color, foam volume, FVSI, and sensory properties.
\end{abstract}




\section{Pendahuluan}

Susu banyak digunakan pada campuran minuman kopi dan pada umumnya yang digunakan adalah susu pasteurisasi yang dibuat dari susu segar. Susu selain memberikan rasa milky juga memiliki kemampuan membentuk dan meningkatkan stabilitas buih yang dihasilkan. Salah satu karakteristik kualitas yang penting dalam minuman kopi mengandung susu seperti cappuccino, latte macchiato, dan latte adalah stabilitas buih. Lapisan buih di bagian atas minuman menentukan kualitas keseluruhan produk dan menjadi daya tarik konsumen karena perannya yang penting terhadap penampilan, volume, tekstur, mouthfeel dan pelepasan aroma kopi (Ho et al., 2019; Illy and Navarini, 2011). Lapisan buih membantu menjebak aroma kopi sehingga aroma kopi pada minuman dapat terjaga lebih lama. Buih susu yang terbentuk harus dapat stabil dalam jangka waktu yang sama dengan jangka waktu mengonsumsi minuman, sekitar 10-15 menit untuk aplikasi pada minuman kopi cappuccino (Huppertz, 2010).

Salah satu jenis susu yang dapat digunakan dalam minuman kopi mengandung susu adalah susu skim sebagian rekombinasi. Susu skim sebagian rekombinasi adalah produk susu cair yang dihasilkan dari penggabungan lemak susu dan padatan susu bukan lemak dengan atau tanpa penambahan air untuk mendapatkan komposisi susu skim sebagian yang sesuai, dan dipasteurisasi atau disterilisasi juga dapat diproses secara UHT (Ultra High Temperature). Karakteristik dasar yang harus terpenuhi adalah kadar lemak susu 0,6\% sampai kurang dari 2,9\% dan kadar protein tidak kurang dari 2,7\% (BPOM, 2019).

Sistem buih pada produk susu dipengaruhi oleh keberadaan protein whey. Fraksi protein pada susu memberikan pengaruh yang signifikan terhadap sifat buih yang dihasilkan (Deotale et al., 2020). Selain itu, kombinasi protein dan lemak berperan penting dalam pembentukan buih serta stabilitas buih pada produk susu (Martínez-Padilla et al., 2015). Partikel lemak susu dalam kondisi alami dikelilingi oleh lapisan fosfolipid dan protein yang disebut milk fat globule membrane (MFGM) yang berfungsi sebagai pengemulsi alami (Lu et al., 2013). Kadar lemak yang tinggi pada produk memberikan kemungkinan lebih besar untuk terbentuknya asam lemak jenuh bebas yang membuat pembentukan buih susu terhambat dan membuat buih susu tidak stabil (Huppertz, 2010). Oleh karen itu penggunaan susu skim akan mengurangi resiko tersebut, karena kandungan lemaknya yang lebih sedikit dibandingkan dengan susu full cream.

Pengurangan lemak dan protein untuk mencapai level tertentu memiliki dampak terhadap tekstur dan pada beberapa kasus berdampak juga pada stabilitas produk. Rasio lemak dan protein yang tidak seimbang mengakibatkan MFGM tidak dapat berfungsi dengan baik yang mengakibatkan produk susu tidak stabil. Hidrokolid atau penstabil dan pengemulsi berperan penting dalam stabilitas dan tekstur produk akhir yang dihasilkan. Penambahan penstabil seperti xanthan gum dan microcrystalline cellulose (MCC) pada foamed milk dapat membantu menstabilkan buih yang terbentuk.
Penambahan xanthan gum (XG) dapat meningkatkan viskositas produk yang dapat membantu meningkatkan stabilitas buih (Khezri et al., 2017). Selain itu, MCC juga dapat digunakan sebagai penstabil karena memiliki karakteristik amphipathic (memiliki dua gugus hidrofilik dan hidrofobik). MCC dapat menstabilkan sistem karena kemampuannya yang fleksibel dalam aktivasi gugus lyophilic dan lyophobic. Kemampuan tersebut dapat membantu dalam proses stabilisasi sistem buih di suatu produk (Nsor-Atindana et al., 2017).

Berdasarkan fakta di atas, penelitian ini bertujuan mendapatkan formulasi susu skim sebagian rekombinasi yang disukai oleh konsumen dan menentukan jenis serta konsentrasi penstabil yang memberikan kestabilan buih yang terbentuk pada proses frothing. Hasil penelitian ini diharapkan dapat memberi acuan dan referensi dalam pengembangan produk susu yang penggunaannya ditujukan sebagai foamed milk pada minuman kopi dengan memperhatikan juga aspek biaya.

\section{Metode}

Penelitian dilakukan pada bulan April sampai dengan Agustus 2020 di perusahaan pengolahan susu yang berlokasi di Jakarta. Bahan-bahan yang digunakan antara lain bahan campuran susu, bubuk whey dari Lactalis- Perancis, laktosa dari Leprino Foods-Amerika, penstabil xanthan gum dari Danisco - Perancis, penstabil microcrystalline cellulose dari Dupont - Thailand.

Peralatan yang digunakan meliputi neraca analitik, mixer ( $\mathrm{T} 25$ digital Ultra Turrax), water bath (Polyscience), milk jug, coffee maker (Saeco Aulika Focus), viskometer (Brookfield-LVT), termometer digital (Ebro-TTX110), ColorFlex EZ spektrofotometer (Hunter LAB, USA), pH meter digital (SI Analytics), dan peralatan gelas. Software yang digunakan adalah Minitab 18 dan Microsoft Excel 2016.

\subsection{Prosedur formulasi susu skim sebagian rekombinasi}

Formulasi susu skim sebagian rekombinasi dibuat dengan karakteristik kadar protein $2,75 \%$, dan kadar lemak 2,30\%. Bahan yang digunakan adalah bahan campuran susu, bubuk whey, dan laktosa. Proses pembuatan dapat dilihat pada Gambar 1. Semua bahan dicampur dengan menggunakan mixer (T 25 digital Ultra Turrax) selama 20 menit dengan kecepatan 7000 rpm, kemudian dilakukan proses pasteurisasi selama 3 menit pada suhu $80{ }^{\circ} \mathrm{C}$. Selanjutnya sampel disimpan dalam refrigerator pada suhu $4{ }^{\circ} \mathrm{C} \pm 1{ }^{\circ} \mathrm{C}$.

Terdapat 5 formula dengan variabel kadar laktosa dan bubuk whey (Tabel 1) yang kemudian dilakukan pre-seleksi dengan metode Focus Group Discussion (FGD) oleh 4 panelis terlatih. FGD dilakukan untuk menentukan atribut sensori serta pengelompokan formula berdasarkan kemiripan rasa. Formula yang akan diuji pada tahap selanjutnya dipilih berdasarkan hasil pengelompokan rasa dan untuk masing-masing kelompok dipilih satu formula. Formula hasil preseleksi selanjutnya diuji hedonik oleh panelis tidak terlatih dengan menggunakan skala 1-9 (kriteria 1: 
amat sangat tidak suka, 5: netral, 9: amat sangat suka) untuk atribut rasa secara keseluruhan (overall taste) dengan tujuan untuk mengetahui tingkat penerimaan terhadap formula yang dibuat.

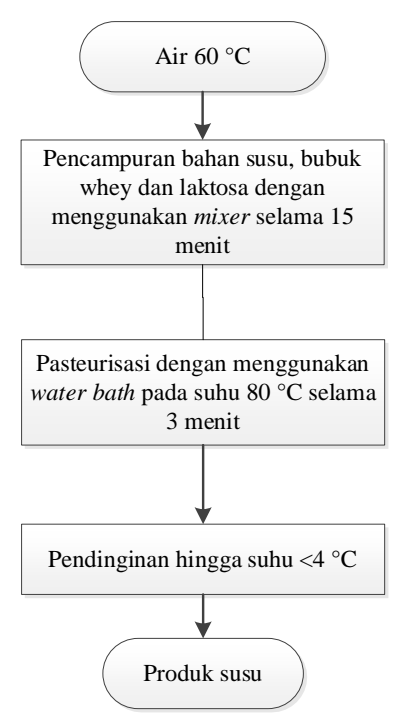

Gambar 1. Proses pembuatan susu skim sebagian rekombinasi pasteurisasi

Tabel 1.

Formula pre-seleksi susu skim sebagian rekombinasi dengan variabel kadar laktosa dan bubuk whey

\begin{tabular}{llllll}
\hline \multirow{2}{*}{ Bahan baku } & \multicolumn{4}{l}{ Berat } \\
\cline { 2 - 6 } & P1 & P2 & P3 & P4 & P5 \\
\hline Bahan & 98,40 & 98,40 & 98,40 & 98,40 & 98,40 \\
campuran susu & 1,60 & 1,20 & 0,80 & 0,40 & 0,00 \\
Laktosa & 0,00 & 0,40 & 0,80 & 1,20 & 1,60 \\
Bubuk whey & 100 & 100 & 100 & 100 & 100 \\
\hline Total & & & & & \\
\hline
\end{tabular}

\subsection{Peningkatan daya buih formula terpilih}

Formula yang paling disukai panelis di tahap pertama digunakan pada tahap berikutnya. Pada tahap ini, formula ditambah dengan penstabil microcrystalline cellulose (MCC) atau xanthan gum (XG) dengan variasi konsentrasi penggunaan seperti pada Tabel 2. Sampel disimpan dalam refrigerator sampai suhu mencapai $4{ }^{\circ} \mathrm{C}$ $\pm 1{ }^{\circ} \mathrm{C}$. Selanjutnya dilakukan frothing dengan metode injeksi uap menggunakan mesin coffee maker dengan target suhu frothing $40{ }^{\circ} \mathrm{C}, 50{ }^{\circ} \mathrm{C}, 60{ }^{\circ} \mathrm{C}$, dan $70{ }^{\circ} \mathrm{C}$. Pada semua sampel dilakukan pengukuran parameter volume buih susu dan foam volume stability index (FVSI) pada rentang waktu 1, 5, 10, 15, dan 20 menit setelah proses frothing, serta dilakukan juga pengukuran viskositas. Masing-masing pengukuran dilakukan sebanyak 3 kali pengulangan. Pada tahap ini selanjutnya dipilih 1 sampel berdasarkan pertimbangan stabilitas buih dan biaya. Biaya formula dihitung dengan menjumlahkan harga masing-masing bahan yang digunakan sehingga didapat biaya formula untuk $1 \mathrm{Kg}$ sampel. Pada sampel terpilih dilakukan tetrad test (uji beda) terhadap sampel kontrol (tanpa penambahan penstabil) untuk mengetahui perbedaannya secara sensori.

Tabel 2.

Variasi konsentrasi penstabil

\begin{tabular}{llll}
\hline No & Sampel & MCC & Xanthan gum \\
\hline 1 & Kontrol & - & - \\
2 & MCC 0,08\% & $0,08 \%$ & \\
3 & MCC 0,10\% & $0,10 \%$ & \\
4 & MCC 0,12\% & $0,12 \%$ & \\
5 & XG 0,10\% & & $0,10 \%$ \\
6 & XG 0,15\% & & $0,15 \%$ \\
7 & XG 0,20\% & $0,20 \%$ \\
\hline
\end{tabular}

\subsection{Uji penyimpanan formula}

Formula terpilih dari tahap kedua dikemas dalam botol kaca (schoot bottle) kemudian dipasteurisasi selama 3 menit pada suhu $80{ }^{\circ} \mathrm{C}$. Sampel disimpan selama 7 hari pada suhu $\leq 4{ }^{\circ} \mathrm{C} \pm 1{ }^{\circ} \mathrm{C}$. Pengamatan sampel dilakukan pada penyimpanan $0,1,3,5$, dan 7 hari. Parameter yang diamati meliputi volume buih, FVSI, pH, viskositas, warna dan sifat sensori dengan metode FGD oleh panelis terlatih. Pada tahap ini digunakan kontrol berupa sampel tanpa penambahan penstabil.

\subsection{Pengukuran volume buih dan foam volume stability index (FVSI)}

Sebanyak $150 \mathrm{~mL}$ sampel dengan suhu $4{ }^{\circ} \mathrm{C}$ ditempatkan ke dalam milk jug dan dilakukan proses frothing dengan metode injeksi uap menggunakan mesin coffee maker. Sampel dituang ke dalam gelas ukur dan dilakukan pengukuran volume buih dan foam volume stability index (FVSI). Pengukuran dilakukan pada rentang waktu 20 menit setelah proses frothing selesai. Rumus perhitungan volume buih dan FVSI :

$$
\begin{gathered}
\text { Vfoam }=V T-V L \\
F V S I=\frac{V \text { foam } t}{V \text { foam } 0} \times 100 \%
\end{gathered}
$$

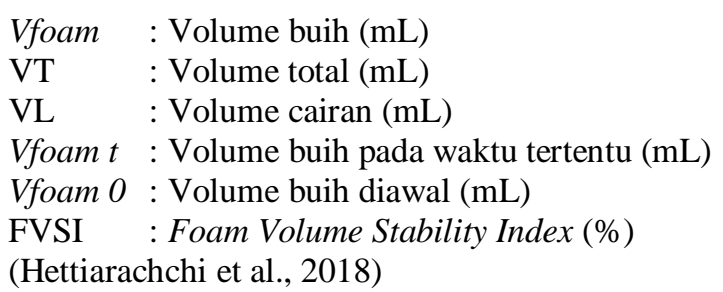

\subsection{Pengukuran pH}

Nilai pH diukur pada suhu $25{ }^{\circ} \mathrm{C}$ dengan menggunakan $\mathrm{pH}$ meter digital (SI Analytics) dengan rentang nilai $\mathrm{pH}$ 0-14 dan dilakukan kalibrasi sebelum digunakan. 


\subsection{Pengukuran viskositas}

Viskositas diukur dengan menggunakan viskometer tipe spindel berputar (Brookfield - LVT). Sampel dituang ke dalam wadah gelas, kemudian spindel diturunkan sampai alur (tanda perendaman) pada poros menyentuh sampel. Level viskometer disesuaikan jika diperlukan. Wadah dipindahkan secara perlahan di bidang horizontal hingga spindel terletak di sekitar tengah wadah. Viskometer dinyalakan dan spindel yang digunakan adalah spindel nomor 61 dengan kecepatan 30 rpm. Spindel dibiarkan berputar sampai jarum penunjuk pada skala stabil. Selanjutnya alat dimatikan dan jarum pembacaan ditahan untuk kemudian dilakukan pembacaan. Faktor skala untuk spindel nomor 61 pada kecepatan $30 \mathrm{rpm}$ adalah 2. Rumus perhitungan viskositas (persamaan 3).

$$
V=f s
$$

$V$ : Viskositas (mPa.s)

$f$ : Faktor skala terhadap ukuran spindel

$s$ : Skala pembacaan

(ASTM, 2014)

\subsection{Pengukuran warna}

Warna diukur dengan parameter $L^{*}, a^{*}, b^{*}$ menggunakan ColorFlex EZ spektrofotometer (Hunter LAB, USA) yang dilengkapi dengan lampu flash xenon D65 sebagai sumber cahaya. Cahaya ini direfleksikan sampel yang ditempatkan pada sample cup khusus dan dipisahkan berdasarkan panjang gelombangnya yang berkisar pada spektrum visibel 400-700 nm. Geometri yang digunakan adalah $45^{\circ} / 0^{\circ}$. Pengukuran triplo dilakukan untuk tiap sampel dan dilakukan perhitungan nilai $\Delta \mathrm{E}$.

$$
\Delta \mathrm{E}=\sqrt{(\Delta L *) 2+(\Delta a *) 2+(\Delta b *) 2}
$$

$\Delta \mathrm{E} \quad$ : total nilai perbedaan warna antara sampel uji dengan pembanding

$\Delta \mathrm{L}^{*} \quad$ : perbedaan nilai kecerahan antara sampel uji dan pembanding

$\Delta a^{*} \quad$ : perbedaan nilai kemerahan (+)/kehijauan (-) antara sampel uji dan pembanding

$\Delta \mathrm{b}^{*} \quad$ : perbedaan nilai kekuningan $(+) /$ kebiruan (-) antara sampel uji dan pembanding

Standar pengamatan perbedaan warna melalui nilai $\Delta \mathrm{E}$ :

$0<\Delta \mathrm{E}<1 \quad$ : tidak terlihat adanya perbedaan

$1<\Delta \mathrm{E}<2$ : hanya dapat dilihat perbedaannya oleh pengamat terlatih

$2<\Delta \mathrm{E}<3,5$ : dapat dilihat perbedaannya oleh pengamat tidak terlatih

$3,5<\Delta \mathrm{E}<5:$ perbedaan cukup terlihat nyata

$5<\Delta \mathrm{E} \quad$ : pengamat dapat membedakan dua warna berbeda

(Mokrzycki and Tatol, 2011)

\subsection{Uji sensori (uji hedonik dan uji tetrad)}

Uji hedonik dilakukan menggunakan 30 panelis tidak terlatih yang merupakan representatif dari konsumen peminum susu (mengonsumsi susu plain minimum 1 kali per bulan). Uji hedonik membutuhkan minimum 20 panelis untuk pilot testing (Singh-Ackbarali and Maharaj, 2014). Susu disajikan kepada panelis dalam kondisi dingin $\pm 10{ }^{\circ} \mathrm{C}$. Uji hedonik dilakukan dengan skala 1-9 dengan kriteria seperti ditunjukkan pada Tabel 3.

Penilaian atribut rasa secara keseluruhan (overall taste) dilakukan dengan tujuan untuk mengetahui tingkat penerimaan terhadap formula yang dibuat. Panelis juga diminta memberikan komentar mengenai produk dan keinginan untuk membeli produk (purchase intent). Nilai purchase intent didapat dari jumlah panelis dengan keinginan membeli dibagi jumlah panelis keseluruhan dan disajikan dalam bentuk persentase (\%). Data diolah menggunakan program Minitab 18 dengan Tukey test $5 \%$ untuk mengetahui formula yang paling disukai panelis.

Tabel 3.

Skala penilaian uji hedonik

\begin{tabular}{ll}
\hline Skala Penilaian & Kriteria \\
\hline 1 & Amat sangat tidak suka \\
2 & Sangat tidak suka \\
3 & Tidak suka \\
4 & Agak tidak suka \\
5 & Netral \\
6 & Agak suka \\
7 & Suka \\
8 & Sangat suka \\
9 & Amat sangat suka \\
\hline
\end{tabular}

(Kemp et al., 2018)

Uji tetrad (tergolong dalam Discriminative Test dan merupakan metode sensitif yang bertujuan untuk mendeteksi perbedaan secara sensori antara 2 sampel uji) dilakukan dengan 2 grup sampel yang ingin diuji diposisikan secara acak dan diberi identitas kode nomor (masing-masing grup terdiri dari 2 sampel yang sama, sehingga secara total ada 4 sampel) dan disajikan pada screened panelist secara simultan. Panelis diminta untuk mencicipi produk berurutan dari ujung kiri ke kanan (diperkenankan untuk mencicip ulang produk) dan diminta untuk mengidentifikasi dua sampel yang sama dengan mencatat identitas kode nomornya pada lembaran yang disediakan. Untuk pengujian ini dibutuhkan lima belas orang screened panelist (dengan 2 kali repetisi) dan kedua sampel yang diuji dinyatakan berbeda nyata $(\mathrm{P}<0.05)$ jika terdapat minimum 16 jawaban benar dari total 30 jawaban yang diperoleh (Rogers, 2017). 


\section{Hasil dan pembahasan \\ 3.1 Formulasi dan uji sensori}

Pre-seleksi formula dilakukan oleh 4 panelis terlatih melalui Focus Group Discussion (FGD). Panelis menentukan atribut yang terdapat pada semua formula kemudian mengelompokkan berdasarkan kesamaan rasa. Pada Tabel 4 dapat dilihat atribut yang terdapat pada semua formula dan atribut yang paling menonjol adalah rasa milky, rasa gurih dan mouthfeel. Selanjutnya, formula dikelompokkan berdasarkan intensitas atribut rendah, intensitas atribut sedang, dan intensitas atribut tinggi.

Tabel 4.

Pengelompokan formula berdasarkan atribut rasa secara keseluruhan

\begin{tabular}{lll}
\hline Formula & Deskripsi atribut & Pengelompokan \\
\hline P1 & $\begin{array}{l}\text { tidak terlalu milky, tidak } \\
\text { gurih, mouthfeel tipis } \\
\text { sedikit lebih milky, } \\
\text { sedikit gurih, mouthfeel } \\
\text { tipis }\end{array}$ & $\begin{array}{l}\text { intensitas atribut } \\
\text { rendah } \\
\text { intensitas atribut } \\
\text { sedang }\end{array}$ \\
& $\begin{array}{l}\text { rasa milky, sedikit gurih, } \\
\text { mouthfeel agak tebal } \\
\text { rasa milky, gurih, } \\
\text { Pouthfeel agak tebal } \\
\text { rasa milky, sangat gurih, } \\
\text { P4 }\end{array}$ & intensitas atribut \\
& intensitas atribut \\
P5feel agak tebal & intensitas atribut \\
& tinggi \\
\hline
\end{tabular}

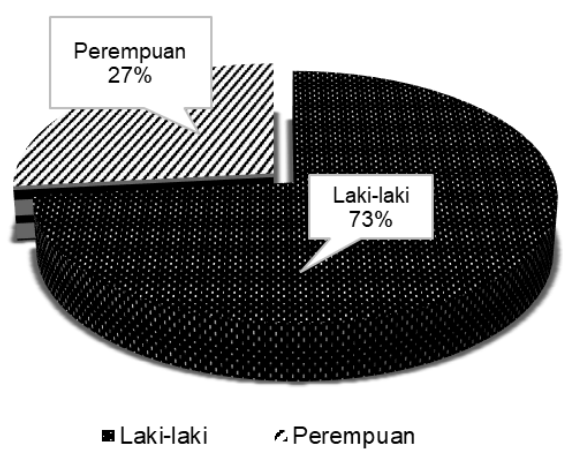

(a)

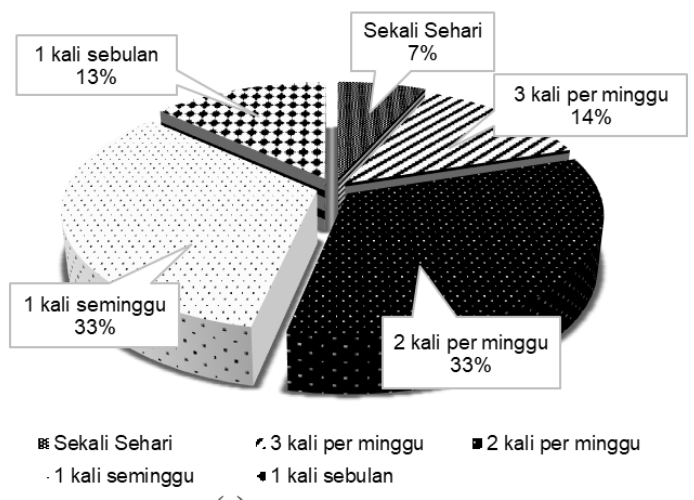

(c)
Selanjutnya dari data tersebut dipilih 3 formula yaitu P1, P2 dan P4 yang mewakili masing-masing kelompok. Formula P1 dipilih untuk mewakili kelompok dengan intensitas atribut rendah karena secara keseluruhan rasa milky, dan mouthfeel lebih rendah dibandingkan formula lainnya. Formula P2 dipilih mewakili kelompok formula dengan intensitas atribut sedang, karena secara keseluruhan rasa cukup seimbang dengan intensitas sedang. Formula P3 tidak dipilih karena memiliki atribut yang lebih menonjol yaitu mouthfeel yang lebih tebal dibandingkan P2 sehingga sedikit beririsan dengan formula pada kelompok dengan intensitas atribut tinggi. Formula P4 dipilih karena secara keseluruhan rasa cukup seimbang dengan intensitas atribut tinggi. Formula P5 tidak dipilih karena intensitas rasa gurih yang cukup tinggi sehingga cukup mengganggu rasa secara keseluruhan. Tiga formula terpilih diuji hedonik menggunakan 30 panelis tidak terlatih sebagai responden.

Profil responden pada penelitian ini dapat dilihat pada Gambar 2. Mayoritas responden adalah laki-laki (73\%), berusia 31-35 tahun (37\%), peminum kopi (73\%), dengan frekuensi mengonsumsi produk susu 1 kali per minggu (33\%) sampai 2 kali per minggu (33\%), dan jenis susu yang paling banyak dikonsumsi adalah susu UHT full cream $(90 \%)$.

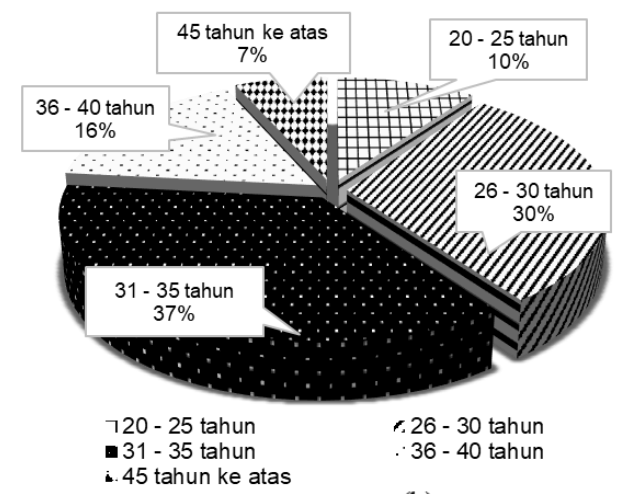

(b)

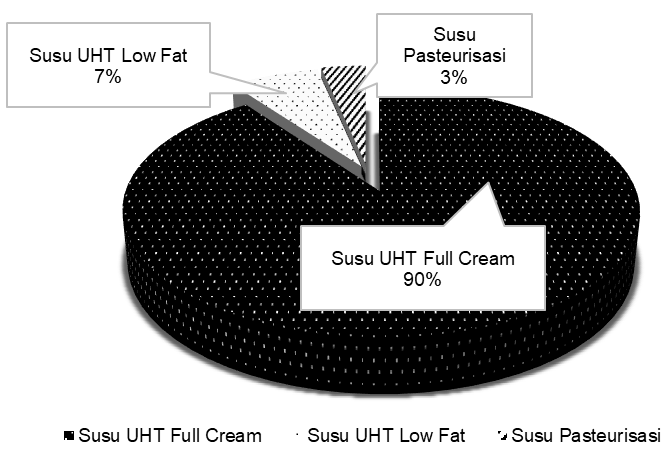

(d)

Gambar 2. Profil responden (a) jenis kelamin, (b) usia responden, (c) tingkat konsumsi susu, (d) jenis susu yang dikonsumsi. 
Hasil uji hedonik ditampilkan pada Tabel 5 yang menunjukkan nilai kesukaan secara keseluruhan untuk formula P1, P2 dan P4 tidak berbeda nyata. Formula P1 memiliki atribut sensori cukup creamy dan gurih, mouthfeel tipis, secara keseluruhan rasa pas, dan tidak terlalu berasa susu dibandingkan dengan formula lain. Formula P2 dan P4 memiliki atribut yang dirasa mengganggu yaitu aftertaste bersisa pada $\mathrm{P} 2$ dan aroma cowy serta rasa agak amis pada P4. Faktor tersebut memengaruhi nilai keinginan membeli panelis terhadap produk. Nilai keinginan membeli untuk formula P1 $76,67 \%$ lebih tinggi dibandingkan dengan formula P2 $70,00 \%$ dan formula P4 56,67\%. Nilai tersebut sejalan dengan penilaian panelis yang menunjukkan bahwa formula P1 memiliki atribut sensori yang lebih baik dibandingkan dengan formula P2 dan P4. Bahan bubuk whey digunakan pada formula P2 dan P4, sedangkan formula P1 tidak menggunakan bubuk whey.

Tabel 5.

Nilai rata-rata kesukaan keseluruhan, keinginan membeli, dan penilaian panelis

\begin{tabular}{|c|c|c|c|}
\hline \multirow{2}{*}{ Parameter } & \multicolumn{3}{|l|}{ Formula } \\
\hline & $\mathrm{P} 1$ & $\mathrm{P} 2$ & $\mathrm{P} 4$ \\
\hline Kesukaan keseluruhan* & $7,07 \mathrm{a}$ & $6,93 a$ & $6,87 \mathrm{a}$ \\
\hline Keinginan membeli (\%) & 76,67 & 70,00 & 56,67 \\
\hline Penilaian panelis & $\begin{array}{l}\text { Sedikit creamy dan gurih, } \\
\text { mouthfeel tipis, secara } \\
\text { keseluruhan rasa pas, } \\
\text { namun tidak terlalu } \\
\text { berasa susu }\end{array}$ & $\begin{array}{l}\text { Rasa creamy dan gurih } \\
\text { lebih tinggi, mouthfeel } \\
\text { sedang, secara } \\
\text { keseluruhan rasa pas, } \\
\text { namun aftertaste bersisa }\end{array}$ & $\begin{array}{l}\text { Sangat creamy, asin dan } \\
\text { gurih, mouthfeel sedang, } \\
\text { secara keseluruhan rasa } \\
\text { pas, namun aftertaste } \\
\text { bersisa, aroma cowy dan } \\
\text { agak amis }\end{array}$ \\
\hline
\end{tabular}

Keterangan : *Huruf yang sama pada baris yang sama menunjukkan tidak berbeda nyata (uji Tukey, tingkat kepercayaan 95\%)

Karakteristik sensori dari bubuk whey adalah asin, asam, creamy, rasa cardboard dan, rasa apek. Senyawa volatil memberikan pengaruh besar terhadap karakter rasa pada bubuk whey. Karakteristik sensori bubuk whey dapat dipengaruhi oleh dua faktor yaitu proses pembuatan dan penyimpanannya. Karakter sensori tersebut dapat terbawa ke produk akhir yang bisa berdampak negatif pada atribut sensori (Carter and Drake, 2018). Berdasarkan hasil ini maka formula P1 dipilih untuk selanjutnya dilakukan peningkatan daya buih dengan penambahan penstabil.

\subsection{Peningkatan daya buih formula terpilih dengan penambahan penstabil}

Gambar 3 menunjukkan sampel dengan penambahan xanthan gum memiliki nilai volume buih yang cenderung lebih tinggi dibandingkan sampel dengan penambahan MCC. Peningkatan volume buih terjadi ketika suhu frothing meningkat dari $40{ }^{\circ} \mathrm{C}$ ke $70{ }^{\circ} \mathrm{C}$.

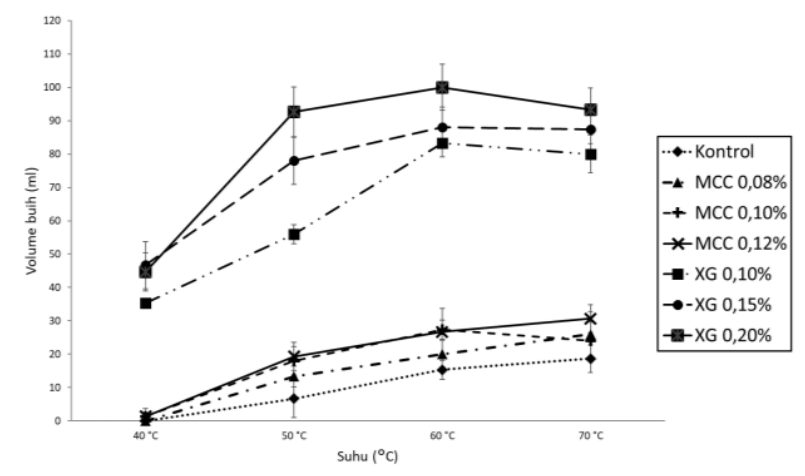

Gambar 3. Volume buih susu pada beberapa suhu frothing
Sampel dengan suhu frothing $60{ }^{\circ} \mathrm{C}$ dan $70{ }^{\circ} \mathrm{C}$ memiliki nilai yang lebih tinggi dibandingkan dengan sampel pada suhu $40{ }^{\circ} \mathrm{C}$ dan $50{ }^{\circ} \mathrm{C}$. Kondisi ini bisa terjadi dikarenakan semakin tinggi suhu frothing maka semakin lama proses injeksi uap dan semakin lama proses aerasi. Volume buih yang terbentuk dengan metode injeksi uap sangat berkaitan dengan jumlah udara yang diinjeksikan dan kemampuan protein di permukaan buih dalam menjaga udara yang terperangkap (Jimenez-Junca et al., 2015). Karena itu, semakin lama waktu frothing maka buih yang terbentuk akan semakin banyak. Di samping itu, selama proses injeksi uap terjadi perubahan struktur ikatan protein yang berdampak pada stabilitas di permukaan buih (Silva et al., 2008).

Peningkatan nilai volume buih berlangsung dari suhu $40{ }^{\circ} \mathrm{C}$ sampai suhu $60{ }^{\circ} \mathrm{C}$. Selanjutnya, pada suhu $70{ }^{\circ} \mathrm{C}$ volume buih tidak menunjukkan perubahan dan relatif sama dengan suhu $60{ }^{\circ} \mathrm{C}$. Hasil uji statistik menunjukkan volume buih susu pada suhu $70{ }^{\circ} \mathrm{C}$ dan $60{ }^{\circ} \mathrm{C}$ tidak berbeda nyata (uji Tukey 5\%), maka dapat dikatakan suhu optimal untuk proses frothing adalah $60^{\circ} \mathrm{C}$. Pada penelitian yang lain disebutkan bahwa suhu menjadi parameter yang memengaruhi proses pembentukan buih susu. Suhu frothing yang digunakan untuk menghasilkan buih yang baik yaitu pada suhu antara $50{ }^{\circ} \mathrm{C}$ dan $60{ }^{\circ} \mathrm{C}$ dari pada suhu yang lebih rendah (Oetjen et al., 2014).

Data pada Gambar 4 dapat dilihat sampel dengan penambahan MCC dan xanthan gum memiliki nilai volume buih yang lebih tinggi dibandingkan dengan kontrol. Menurut (Khezri et al., 2017) penambahan penstabil seperti MCC dan xanthan gum pada foamed milk dapat membantu menstabilkan buih yang terbentuk.

Penambahan xanthan gum memberikan efek yang baik pada stabilitas buih di minuman susu. Viskositas meningkat dengan adanya penambahan xanthan gum dan peningkatan viskositas dapat mengurangi laju 
penggabungan buih dan meningkatkan stabilitas buih. Dengan meningkatnya viskositas fase kontinu maka waktu kohesi dua gelembung akan meningkat. Peningkatan konsentrasi xanthan gum memiliki efek pada kepadatan fase yang mengakibatkan terjadinya perbedaan kerapatan antara dua fase. Adanya perbedaan kerapatan akan meningkatkan luas permukaan kontak, dan fase terdispersi akan lebih stabil (Khezri et al., 2017).

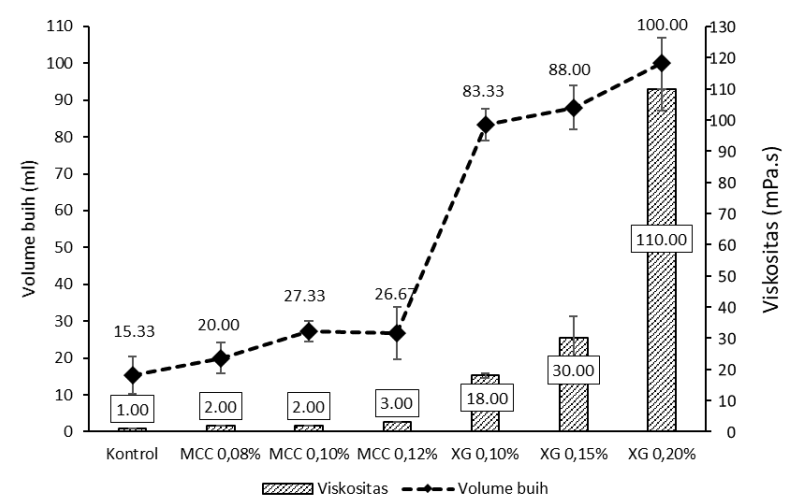

Gambar 4. Hubungan viskositas dan volume buih

Atribut lain yang dapat dilihat sebagai indikasi daya buih yang baik adalah nilai FVSI. Nilai ini merupakan hasil perbandingan volume buih setelah waktu tertentu terhadap volume buih di awal. Semakin tinggi nilai FVSI menunjukkan semakin stabil buih susu selama rentang waktu tertentu.

Pada Gambar 5 dapat dilihat nilai FVSI yang diukur pada rentang waktu 20 menit setelah proses frothing. Nilai FVSI meningkat seiring dengan kenaikan suhu frothing. Setelah melewati suhu $60{ }^{\circ} \mathrm{C}$, nilai FVSI tidak lagi meningkat dan cenderung sama pada suhu $70{ }^{\circ} \mathrm{C}$. Whey protein dalam suhu yang lebih tinggi yaitu pada suhu 60-70 ${ }^{\circ} \mathrm{C}$ akan mengalami proses denaturasi. Meningkatnya protein yang terdenaturasi ini mengakibatkan pembentukan jaringan yang lebih kuat dan stabil antara kasein dan protein whey. Jaringan kasein dan protein whey ini berada pada lapisan permukaan buih. Kondisi ini yang dapat mengakibatkan proses pelepasan udara dari gelembung menjadi terhambat dan meningkatkan stabilitas buih yang terbentuk (Silva et al., 2008).

Sampel dengan penambahan MCC memiliki viskositas yang tidak berbeda nyata dengan kontrol (uji Dunnett, level kepercayaan 95\%). Menurut penelitian lain, penambahan MCC pada sampel sampai konsentrasi $0,10 \%$ tidak memberikan perubahan viskositas yang nyata (Sumonsiri et al., 2018). Sebaliknya sampel dengan penambahan xanthan gum memiliki viskositas lebih besar dibandingkan dengan kontrol. Pada Gambar 6 dapat dilihat bahwa kenaikan nilai viskositas berbanding lurus dengan kenaikan nilai FVSI, semakin tinggi nilai viskositas maka semakin tinggi nilai FVSI. Sampel dengan viskositas lebih besar dapat menahan udara yang berada pada gelembung. Adanya peningkatan viskositas pada sampel akan meningkatkan stabilitas buih (Deotale et al., 2020).

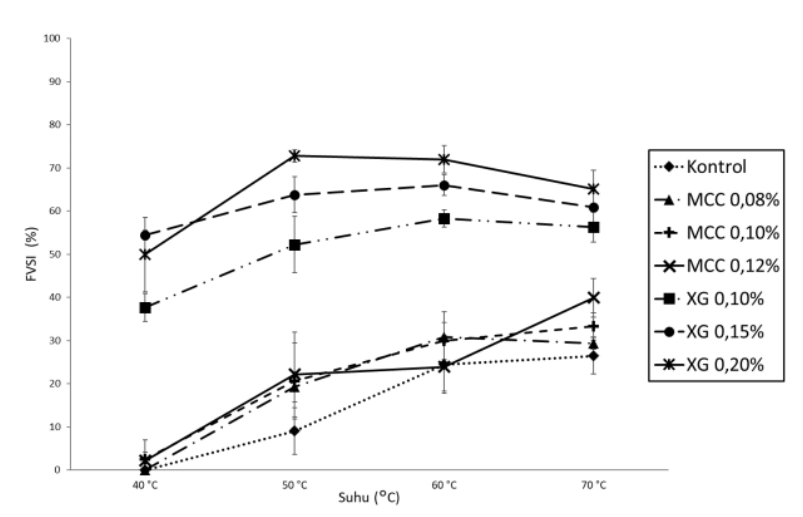

Gambar 5. Foam Volume Stability Index (FVSI) pada beberapa suhu frothing

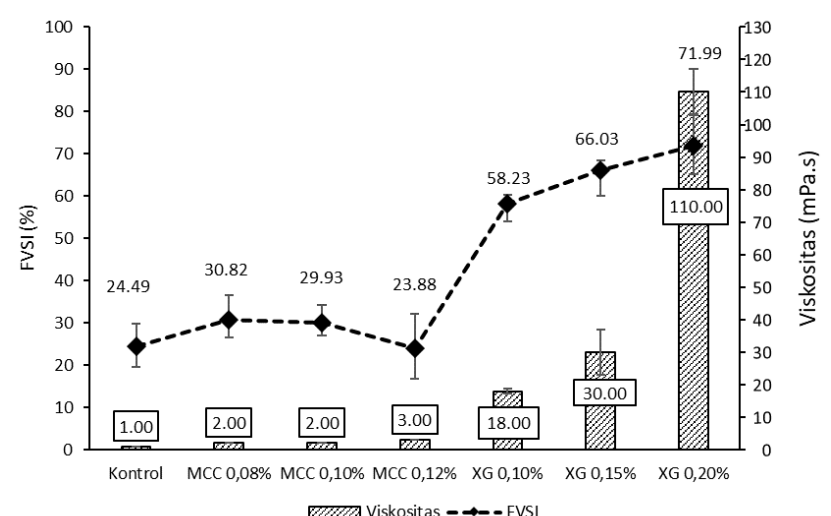

Gambar 6. Hubungan viskositas dan FVSI

Pada Tabel 6 dapat dilihat bahwa volume buih sampel dengan penambahan MCC tidak berbeda nyata dengan kontrol. Sebaliknya, nilai volume buih sampel dengan penambahan xanthan gum berbeda nyata dengan kontrol. Selanjutnya, nilai FVSI sampel dengan penambahan MCC tidak berbeda nyata dengan kontrol. Sebaliknya nilai FVSI sampel dengan penambahan xanthan gum berbeda nyata dengan kontrol.

Berdasarkan hasil pada Tabel 6 , jenis penstabil yang dapat meningkatkan daya buih adalah xanthan gum dengan konsentrasi optimal sebesar 0,10\%. Di samping itu, biaya formula dengan penambahan xanthan gum $0,10 \%$ lebih rendah dibandingkan sampel dengan penambahan xanthan gum $0,15 \%$ dan $0,20 \%$.

Sampel dengan penambahan xanthan gum 0,10\% selanjutnya diuji beda (tetrad test) dan hasilnya menunjukkan 21 respon benar dari total 30 respon. Jumlah tersebut telah melewati batas maksimal respon berbeda nyata yaitu 16 respon (95\% level kepercayaan). Jadi, sampel dengan penambahan penstabil xanthan gam $0,10 \%$ secara sensori (rasa keseluruhan) berbeda nyata dibandingkan dengan kontrol. Hal tersebut dapat terjadi karena adanya perbedaan nilai viskositas yang nyata antara sampel dengan penambahan xanthan gum $0,10 \%$ dengan kontrol seperti ditunjukkan pada Tabel 6 . Perbedaan nilai viskositas ini dapat dirasakan oleh panelis sebagai perbedaan mouthfeel sehingga memengaruhi rasa sampel. 
Tabel 6.

Nilai rata-rata volume buih, FVSI, viskositas dan biaya formula

\begin{tabular}{lllll}
\hline Sampel & Volume buih $(\mathrm{mL})$ & FVSI $(\%)$ & Viskositas $(\mathrm{mPa} . \mathrm{s})$ & Biaya Formula $(\mathrm{Rp} / \mathrm{Kg})$ \\
\hline Kontrol & $15,33 \pm 2,82 \mathrm{a}$ & $24,49 \pm 6,70 \mathrm{a}$ & $1 \pm 0,00 \mathrm{a}$ & $6.007,00$ \\
MCC 0,08\% & $20,00 \pm 4,24 \mathrm{a}$ & $30,82 \pm 5,80 \mathrm{a}$ & $2 \pm 0,00 \mathrm{a}$ & $6.120,00$ \\
MCC 0,10\% & $27,33 \pm 2,82 \mathrm{a}$ & $29,93 \pm 4,27 \mathrm{a}$ & $2 \pm 0,00 \mathrm{a}$ & $6.147,00$ \\
MCC 0,12\% & $26,67 \pm 7,07 \mathrm{a}$ & $23,88 \pm 5,60 \mathrm{a}$ & $3 \pm 0,00 \mathrm{a}$ & $6.174,00$ \\
XG 0,10\% & $83,33 \pm 4,24$ & $58,23 \pm 2,00$ & $18 \pm 0,71$ & $6.176,00$ \\
XG 0,15\% & $88,00 \pm 6,00$ & $66,03 \pm 2,43$ & $30 \pm 7,00$ & $6.258,00$ \\
XG 0,20\% & $100,00 \pm 6,90$ & $71,99 \pm 3,22$ & $110 \pm 7,00$ & $6.343,00$ \\
\hline
\end{tabular}

Keterangan : Nilai tanpa penambahan huruf a pada kolom yang sama menunjukkan berbeda nyata dengan sampel Kontrol (uji Dunnett, level kepercayaan 95\%)

Hasil analisis komposisi kimia sampel dengan xanthan gum $0,10 \%$ dapat dilihat pada Tabel 7. Hasil analisa yang didapat relatif sama dengan hasil perhitungan dan memenuhi kriteria kategori pangan susu skim sebagian rekombinasi. Karakteristik dasar susu skim sebagian rekombinasi yaitu kadar lemak susu 0,60\%-2,90\% dan kadar protein tidak kurang dari 2,70\% (BPOM, 2019).

Tabel 7.

Komposisi kimia sampel dengan xanthan gum $0,10 \%$

\begin{tabular}{lll}
\hline Parameter & $\begin{array}{l}\text { Hasil analisis } \\
(\% \mathrm{~b} / \mathrm{b})\end{array}$ & $\begin{array}{l}\text { Hasil perhitungan } \\
(\% \mathrm{~b} / \mathrm{b})\end{array}$ \\
\hline Total padatan & 11,84 & 11,70 \\
Kadar protein & 2,70 & 2,77 \\
Kadar lemak & 2,22 & 2,30 \\
\hline
\end{tabular}

\subsection{Daya buih dan sifat sensori produk selama penyimpanan}

Sampel dengan penambahan xanthan gum $0,10 \%$ diukur nilai $\mathrm{pH}$, viskositas, volume buih, FVSI, warna dan uji sensori produk selama penyimpanan $(0,1,3,5$, dan 7 hari). Pada Gambar 7 dapat dilihat nilai $\mathrm{pH}$ XG $0,10 \%$ dan kontrol yang relatif sama dan tidak berubah selama penyimpanan. Sampel dengan penambahan xanthan gum memiliki stabilitas $\mathrm{pH}$ yang cukup baik (Li and de Vries, 2018). Nilai pH XG 0,10\% dan kontrol selama penyimpanan 0-7 hari yaitu 6,68-6,76. Penyimpanan susu segar dan susu pasteurisasi pada suhu $4{ }^{\circ} \mathrm{C}$ tidak menunjukkan perubahan nilai $\mathrm{pH}$ di hari ke-5 sampai hari ke-16 (BermÚdez-Aguirre et al., 2009).

Perubahan nilai $\mathrm{pH}$ akan menyebabkan perubahan pada muatan ion dan struktur protein atau pada jumlah kasein, kalsium dan fosfat di dalam serum (Huppertz, 2010). Semua perubahan tersebut akan berdampak pada sifat reologi lapisan permukaan buih, viskositas susu dan selanjutnya berdampak juga pada daya buih susu (BermÚdez-Aguirre et al., 2009).

Pada Gambar 8 dapat dilihat data viskositas XG $0,10 \%$ dan kontrol selama penyimpanan 0-7 hari. Nilai rata-rata viskositas $\mathrm{XG} 0,10 \%$ yaitu $13 \mathrm{mPa}$.s dan tidak berbeda nyata selama penyimpanan hari ke-0 sampai hari ke-7. Hal sama terlihat juga pada nilai rata-rata viskositas kontrol yaitu $1 \mathrm{mPa} . \mathrm{s}$ yang tidak berbeda nyata selama penyimpanan hari ke-0 sampai hari ke-7 (uji Dunnett, level kepercayaan 95\%). Proses penyimpanan pada suhu $4{ }^{\circ} \mathrm{C} \pm 1{ }^{\circ} \mathrm{C}$ selama 7 hari tidak berdampak nyata terhadap nilai $\mathrm{pH}$ dan viskositas $\mathrm{XG}$ $0,10 \%$.

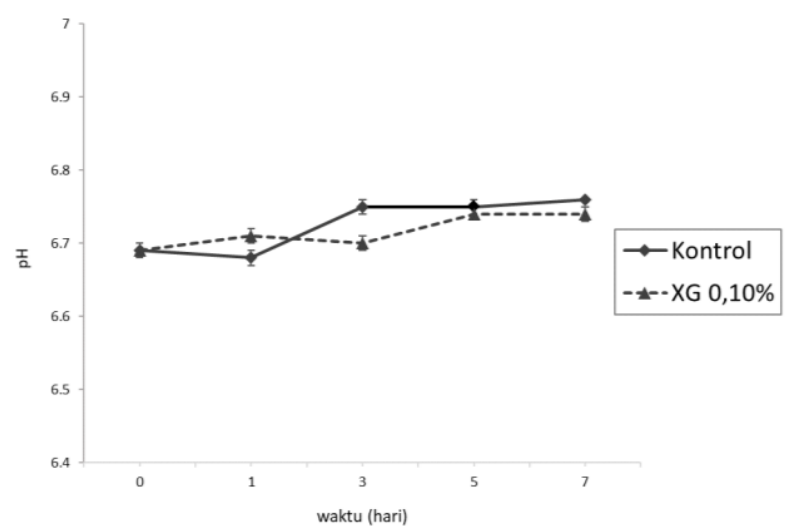

Gambar 7. Nilai pH kontrol dan XG 0,10\% diukur selama penyimpanan

Xanthan gum merupakan polimer anionik dan cukup sensitif dengan perubahan nilai $\mathrm{pH}$ di bawah 4 . Perubahan nilai $\mathrm{pH}$ di bawah 4 akan memengaruhi interaksi diantara molekul xanthan gum. Penurunan nilai $\mathrm{pH}$ akan mengubah gugus karboksil yang sebelumnya dalam bentuk ion menjadi bentuk tanpa ion $\left(\mathrm{COO}^{-}+\mathrm{H}^{+}\right.$ $=\mathrm{COOH})$. Perubahan tersebut mengakibatkan perubahan bentuk molekul yang lebih kecil sehingga berdampak pada penurunan nilai viskositas (Yoon and Yoo, 2016). Meskipun cukup sensitif terhadap perubahan nilai $\mathrm{pH}$ namun pada $\mathrm{pH}$ netral, viskositas larutan xanthan gum cukup stabil.

Pada Gambar 9 dapat dilihat nilai volume buih XG $0,10 \%$ dan kontrol selama penyimpanan. Nilai volume buih pada penyimpanan hari ke-0 sampai hari ke-7 relatif sama dan tidak berbeda nyata (uji Dunnett, level kepercayaan 95\%). Tidak ada perbedaan nyata volume buih sampel pada hari ke-1, hari ke-10 dan hari ke-15. Perubahan karakter buih susu dapat terjadi selama proses penyimpanan di lemari es (suhu $4^{\circ} \mathrm{C}$ ). Perubahan karakter buih susu dan daya buih bisa disebabkan oleh adanya hidrolisis protein susu (sebagai hasil aktifitas 
mikroorganisme) yang menyebabkan penurunan $\mathrm{pH}$ (Madimutsa et al., 2018).

Penyimpanan pada suhu $4^{\circ} \mathrm{C} \pm 1^{\circ} \mathrm{C}$ selama 7 hari tidak berdampak pada perubahan nilai viskositas dan $\mathrm{pH}$. Kedua faktor tersebut sangat berperan pada karakter buih, daya buih dan stabilitas buih. Oleh karena itu, nilai volume buih XG $0,10 \%$ relatif sama selama penyimpanan dengan tidak adanya perubahan pada nilai viskositas dan $\mathrm{pH}$.

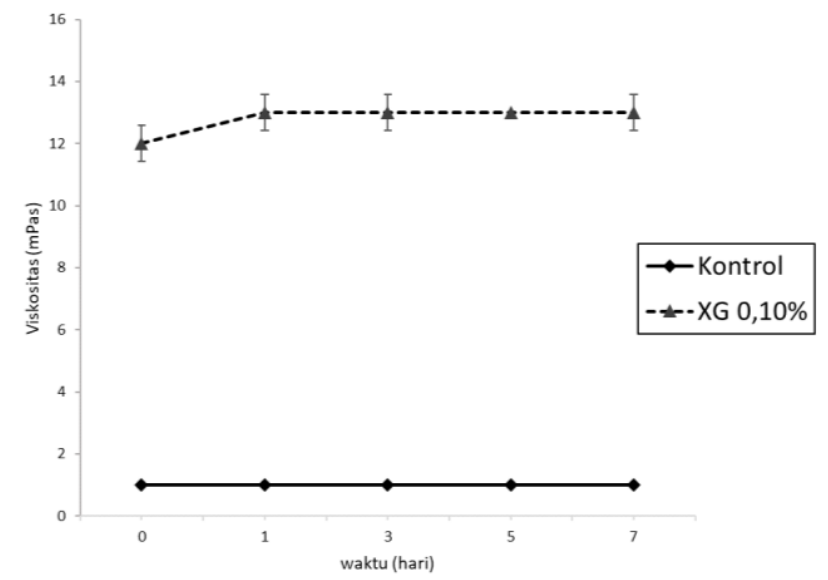

Gambar 8. Viskositas sampel diukur selama penyimpanan

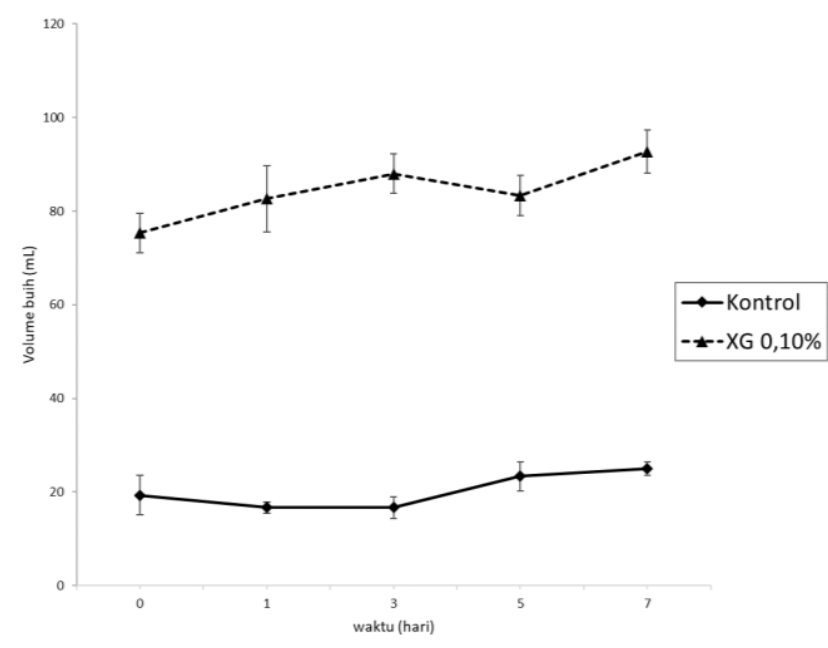

Gambar 9. Nilai rata-rata volume buih diukur selama penyimpanan

Pada Gambar 10 dapat dilihat nilai rata-rata FVSI pada XG $0,10 \%$ dan kontrol tidak berbeda nyata selama penyimpanan hari ke-0 sampai hari ke-7 (uji Dunnett, level kepercayaan 95\%). Stabilitas buih dan volume buih susu pasteurisasi pada hari ke-3 dan hari ke-21 tidak mengalami perubahan yang nyata (Ho et al., 2019). Lama penyimpanan pada suhu $4{ }^{\circ} \mathrm{C} \pm 1{ }^{\circ} \mathrm{C}$ tidak berpengaruh nyata terhadap volume buih dan stabilitas buih. Hal ini bisa terjadi karena penyimpanan pada suhu $4{ }^{\circ} \mathrm{C} \pm 1{ }^{\circ} \mathrm{C} \quad$ selama 7 hari tidak mengakibatkan perubahan yang nyata pada sifat fisik sampel. Nilai $\mathrm{pH}$ dan viskositas XG 0,10\% pada hari ke-0 sampai hari ke7 relatif sama.

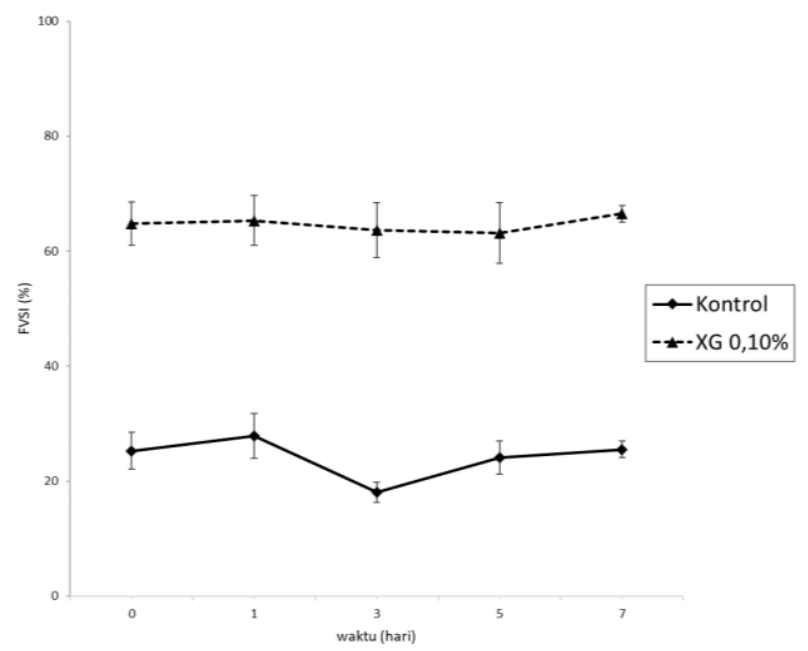

Gambar 10. Nilai rata-rata FVSI diukur selama penyimpanan

Data sensori sampel selama penyimpanan 0-7 hari ditunjukkan pada Tabel 8. Data tersebut didapat melalui Focus Group Discussion (FGD) dengan metode Profile Attribute Analysis (PAA) oleh 4 orang panelis terlatih. Metode PAA dapat dilakukan oleh 4-6 panelis terlatih yang sudah terbiasa dalam penentuan atribut sensori produk dan sudah sangat mengenali atribut sensori untuk kategori produk yang sama (Kemp et al., 2018).

Penilaian untuk masing-masing atribut menggunakan skala 1-5 (kriteria 1: sangat rendah, 3: sedang, dan 5: sangat tinggi). Profil sensori produk pada penyimpanan 0 hari menunjukkan sampel XG $0,10 \%$ memiliki rasa milky dan mouthfeel yang lebih tinggi dibandingkan dengan kontrol. Sampel dengan karakter ukuran buih yang lebih kecil dan stabil lebih disukai karena memiliki mouthfeel yang cenderung lebih lembut (Hatakeyama et al., 2019). Namun rasa asin pada kontrol sedikit lebih tinggi dibandingkan dengan sampel XG $0,10 \%$. Selanjutnya pada penyimpanan hari ke-1 secara keseluruhan profil sensori sama dengan hari ke-0.

Tabel 8.

Profil sensori sampel kontrol dan XG $0,10 \%$ pada 0 hari, 1 hari, 5 hari, 7 hari penyimpanan pada suhu $4^{\circ} \mathrm{C}$

\begin{tabular}{lllllllll}
\hline \multirow{2}{*}{$\begin{array}{l}\text { Penyimpanan } \\
\text { (hari) }\end{array}$} & Kontrol & \multicolumn{7}{c}{ XG 0,10\% } \\
\cline { 2 - 9 } & Gurih & Milky & Mouthfeel & Asin & Gurih & Milky & Mouthfeel & Asin \\
\hline 0 & 3 & 2 & 3 & 3 & 3 & 3 & 4 & 2 \\
1 & 3 & 2 & 3 & 3 & 3 & 3 & 4 & 2 \\
5 & 3 & 2 & 3 & 3 & 3 & 3 & 3 & 2 \\
7 & 3 & 2 & 3 & 3 & 3 & 3 & 3 & 2 \\
\hline
\end{tabular}


Penggunaan xanthan gum dapat meningkatkan viskositas dan berdampak pada atribut mouthfeel yang dirasakan lebih tinggi dibandingkan dengan kontrol. Pengujian pada hari ke-5 dan hari ke-7 menunjukkan sampel XG 0,10\% memiliki rasa milky yang lebih tinggi dan rasa asin yang lebih rendah dibandingkan dengan kontrol. Namun tidak ada perbedaan pada atribut mouthfeel dan rasa gurih. Penambahan xanthan gum memberikan pengaruh terhadap rasa milky yang lebih tinggi dan rasa asin yang lebih rendah.

Hasil pengukuran warna sampel dengan hunter Lab pada hari ke-0 sampai hari ke-7 dapat dilihat pada Tabel 9. Berdasarkan data, nilai $L^{*}$ untuk XG $0,10 \%$ sedikit lebih rendah dibandingkan kontrol di semua waktu penyimpanan. Nilai $L^{*}$ XG $0,10 \%$ lebih rendah yang menunjukkan secara visual lebih gelap dibandingkan dengan kontrol. Nilai a* untuk XG 0,10\% dan kontrol relatif sama pada semua waktu penyimpanan. Selanjutnya, nilai $b^{*}$ untuk XG $0,10 \%$ sedikit lebih tinggi dibandingkan dengan kontrol yang artinya secara visual sampel XG 0,10\% lebih kekuningan. Akan tetapi hasil perhitungan $\Delta \mathrm{E} X \mathrm{XG} 0,10 \%$ pada hari ke-0 sampai hari ke-7 menunjukkan nilai lebih kecil dari 1 atau tidak terlihat adanya perbedaan. Oleh karena itu XG 0,01\% secara visual tidak dapat dibedakan dengan kontrol. Penambahan xanthan gum berfungsi sebagai penstabil atau pengental dan tidak berdampak pada warna sampel. Kandungan xanthan gum adalah polisakarida, dan dalam bentuk larutan tidak memberikan warna sehingga penggunaannya dalam aplikasi minuman tidak berdampak pada perubahan warna sampel (Stephen et al., 2016).

Tabel 9.

Pengukuran parameter warna selama penyimpanan

\begin{tabular}{llllllll}
\hline \multirow{2}{*}{$\begin{array}{l}\text { Penyimpanan } \\
\text { (hari) }\end{array}$} & Kontrol & \multicolumn{7}{c}{ XG 0,10\% } & \multicolumn{1}{c}{$\Delta \mathrm{E}$} \\
\cline { 2 - 7 } & $\mathrm{L}^{*}$ & $\mathrm{a}^{*}$ & $\mathrm{~b}^{*}$ & $\mathrm{~L}^{*}$ & $\mathrm{a}^{*}$ & $\mathrm{~b}^{*}$ & \\
\hline 0 & $92,63 \pm 0,02$ & $-0,42 \pm 0,03$ & $13,53 \pm 0,04$ & $91,79 \pm 0,00$ & $-0,47 \pm 0,02$ & $13,79 \pm 0,07$ & 0,88 \\
1 & $91,99 \pm 0,09$ & $-0,59 \pm 0,03$ & $13,25 \pm 0,03$ & $91,49 \pm 0,07$ & $-0,55 \pm 0,06$ & $13,28 \pm 0,08$ & 0,50 \\
3 & $92,38 \pm 0,01$ & $-0,51 \pm 0,04$ & $13,85 \pm 0,05$ & $91,86 \pm 0,06$ & $-0,51 \pm 0,02$ & $14,02 \pm 0,07$ & 0,55 \\
5 & $92,25 \pm 0,00$ & $-0,80 \pm 0,03$ & $13,09 \pm 0,06$ & $91,81 \pm 0,05$ & $-0,79 \pm 0,05$ & $13,26 \pm 0,01$ & 0,48 \\
7 & $92,46 \pm 0,01$ & $-0,74 \pm 0,03$ & $13,06 \pm 0,04$ & $91,94 \pm 0,08$ & $-0,74 \pm 0,07$ & $13,26 \pm 0,05$ & 0,56 \\
\hline
\end{tabular}

Keterangan:*) L* = Ligthness/kecerahan, $\mathrm{a}^{*}=$ kemerahan (+)/kehijauan (-), dan $\mathrm{b}^{*}=$ kekuningan (+)/kebiruan (-).

\section{Kesimpulan}

Formula susu skim sebagian rekombinasi yang paling disukai oleh panelis adalah formula dengan kadar laktosa $1,60 \%$. Penambahan penstabil microcrystalline cellulose (MCC) tidak memberikan peningkatan daya buih yang nyata dibandingkan dengan kontrol. Sebaliknya penambahan penstabil xanthan gum pada semua variabel konsentrasi $0,10 \%, 0,15 \%$, dan 0,20\% dapat memberikan peningkatan daya buih yang nyata dibandingkan dengan kontrol. Faktor lain yang berpengaruh terhadap daya buih sampel adalah suhu proses frothing. Pembentukan buih susu dengan metode injeksi uap lebih baik pada suhu $60^{\circ} \mathrm{C}$. Penambahan xanthan gum $0,10 \%$ memberikan peningkatan daya buih yang nyata dibandingkan dengan kontrol. Akan tetapi penambahan ini juga berdampak nyata terhadap sifat sensori. Sampel susu skim sebagian dengan penambahan xanthan gum $0,10 \%$ yang disimpan selama $0-7$ hari pada suhu $4^{\circ} \mathrm{C}$ memiliki nilai volume buih dan FVSI yang tidak berbeda nyata serta sifat sensori (atribut gurih, milky dan asin) yang sama. Sampel dengan penambahan xanthan gum $0,10 \%$ memiliki daya buih yang stabil selama penyimpanan.

\section{Saran}

Optimasi konsentrasi xanthan gum dapat dilakukan pada konsentrasi lebih rendah 0,07-0,10\% untuk mendapatkan sampel dengan daya buih yang masih baik tanpa memengaruhi aspek sensori. Di samping itu, dengan konsentrasi yang lebih rendah maka dapat mengurangi biaya formula secara keseluruhan. Selanjutnya, penelitian ini masih dalam skala laboratorium sehingga perlu dilakukan pengujian dalam skala yang lebih besar (skala industri).

\section{Daftar pustaka}

ASTM, 2014. Standard test methods for rheological properties of non-Newtonian materials by rotational (Brookfield type) Viscometer $143,1-5$. https://doi.org/10.1520/D2196-10.2

BermÚdez-Aguirre, D., Mawson, R., Versteeg, K., Barbosa-CÁnovas, G. V., 2009. Composition properties, physicochemical characteristics and shelf life of whole milk after thermal and thermosonication treatments. J. Food Qual. 32, 283-302. https://doi.org/10.1111/j.1745-4557.2009.00250.x

BPOM, B.P.O. dan M.I., 2019. PerKBPOM Nomor 34 Tahun 2019 Tentang Kategori Pangan. Badan Pengawas Obat dan Makanan 1-155.

Carter, B.G., Drake, M.A., 2018. Invited review: The effects of processing parameters on the flavor of whey protein ingredients. J. Dairy Sci. 101, 66916702. https://doi.org/10.3168/jds.2018-14571

Deotale, S., Dutta, S., Moses, J.A., Balasubramaniam, V.M., Anandharamakrishnan, C., 2020. Foaming characteristics of beverages and its relevance to food processing. Food Eng. Rev. 12, 229-250. https://doi.org/10.1007/s12393-020-09213-4

Hatakeyama, S., Akiyama, M., Yoneyama, R., 
Watanabe, K., Koizumi, R., Miyaji, K., Mizota, Y., Ikeda, M., Wakao, S., 2019. Effects of manufacturing conditions on the foaming properties of milk and sensory characteristics of foamed milk. Lwt. https://doi.org/10.1016/j.lwt.2018.09.082

Hettiarachchi, C.A., Corzo-Martínez, M., Mohan, M.S., Harte, F.M., 2018. Enhanced foaming and emulsifying properties of high-pressure-jet-processed skim milk. Int. Dairy J. 87, 60-66. https://doi.org/10.1016/j.idairyj.2018.06.004

Ho, T.M., Le, T.H.A., Yan, A., Bhandari, B.R., Bansal, N., 2019. Foaming properties and foam structure of milk during storage. Food Res. Int. 116, 379-386. https://doi.org/10.1016/j.foodres.2018.08.051

Huppertz, T., 2010. Foaming properties of milk: A review of the influence of composition and processing. Int. J. Dairy Technol. 63, 477-488. https://doi.org/10.1111/j.1471-0307.2010.00629.x

Illy, E., Navarini, L., 2011. Neglected food bubbles: the espresso coffee foam. Food Biophys. 6, 335-348. https://doi.org/10.1007/s11483-011-9220-5

Jimenez-Junca, C., Sher, A., Gumy, J.C., Niranjan, K., 2015. Production of milk foams by steam injection: The effects of steam pressure and nozzle design. J. Food Eng. 166, 247-254. https://doi.org/10.1016/j.jfoodeng.2015.05.035

Kemp, S.E., Hort, J., Hollowood, T., 2018. Descriptive analysis in sensory evaluation a series of books on selected topics in the field of Sensory Evaluation.

Khezri, M., Shahriari, S., Shahsavani, L., 2017. The effect of xanthan gum and temperature on foam stability of milk-based espresso coffees. J. Food Biosci. Technol. 7, 15-22.

Li, X., de Vries, R., 2018. Interfacial stabilization using complexes of plant proteins and polysaccharides. Curr. Opin. Food Sci. 21, 51-56. https://doi.org/10.1016/j.cofs.2018.05.012

Lu, C., Wang, G., Li, Y., Zhang, L., 2013. Effects of homogenisation pressures on physicochemical changes in different layers of ultra-high temperature whole milk during storage. Int. J. Dairy Technol. 66, 325-332. https://doi.org/10.1111/1471-0307.12055

Madimutsa, O.N., Gwala, W., Mujuru, F., Nyambi, C., 2018. Investigation of factors affecting frothing capacity of pasteurised whole milk for cappuccino
Coffee VI, 144-151.

Martínez-Padilla, L.P., García-Rivera, J.L., RomeroArreola, V., Casas-Alencáster, N.B., 2015. Effects of xanthan gum rheology on the foaming properties of whey protein concentrate. J. Food Eng. 156, 22-30. https://doi.org/10.1016/j.jfoodeng.2015.01.018

Mokrzycki, W., Tatol, M., 2011. Color difference Delta E - A survey. Mach. Graph. Vis. 20, 383-411.

Nsor-Atindana, J., Chen, M., Goff, H.D., Zhong, F., Sharif, H.R., Li, Y., 2017. Functionality and nutritional aspects of microcrystalline cellulose in food. Carbohydr. Polym. 172, 159-174. https://doi.org/10.1016/j.carbpol.2017.04.021

Oetjen, K., Bilke-Krause, C., Madani, M., Willers, T., 2014. Temperature effect on foamability, foam stability, and foam structure of milk. Colloids Surfaces A Physicochem. Eng. Asp. https://doi.org/10.1016/j.colsurfa.2014.01.086

Rogers, L., 2017. Discrimination testing in sensory science: A Practical Handbook. Discrim. Test. Sens. Sci. A Pract. Handb.

Silva, S., Espiga, A., Niranjan, K., Livings, S., Gumy, J.C., Sher, A., 2008. Formation and stability of milk foams, Bubbles in Food 2: Novelty, Health and Luxury. AACC International, Inc. https://doi.org/10.1016/B978-1-891127-59-5.50020-1

Singh-Ackbarali, D., Maharaj, R., 2014. Sensory evaluation as a tool in determining acceptability of innovative products developed by undergraduate students in food science and technology at The University of Trinidad and Tobago. J. Curric. Teach. 3, 10-27. https://doi.org/10.5430/jct.v3n1p10

Stephen, A.M., Phillips, G.O., Williams, P.A., 2016. Food polysaccharides and their applications: Second Edition, Food Polysaccharides and Their Applications: Second Edition.

Sumonsiri, N., Kundacha, N., Pom-Iam, N., 2018. Effect of microcrystalline cellulose on physical characteristics and sensory acceptance of chocolate flavored milk. Curr. Res. Nutr. Food Sci. 6, 781-788. https://doi.org/10.12944/CRNFSJ.6.3.20

Yoon, S.-N., Yoo, B., 2016. Effect of pH on rheological properties of dysphagia-oriented thickened water. Prev. Nutr. Food Sci. 31, 73-77. 